\title{
PENCARIAN OTENTISITAS DIRI KOMUNITAS MU'ALLAF DI KABUPATEN SORONG PAPUA BARAT
}

\section{Self Authenticity Quest of Muallaf Community in Sorong, West Papua}

\author{
Munawir Haris \\ Sekolah Tinggi Agama Islam Negeri Sorong \\ Jl. Sorong-Klamono KM 17 Klablim Kota Sorong \\ Email:muha_muna@yahoo.com.co.id
}

Naskah diterima tanggal 1 Juli 2014. Naskah direvisi tanggal 29 September 2014. Naskah disetujui tanggal 7 Oktober 2014

\begin{abstract}
Abstrak
Konversi agama jelas bukan masalah sederhana di tanah Papua. Perpindahan agama yang dilakukan komunitas muallaf membawa berbagai reaksi keras dari berbagai pihak, temasuk oknum aparat dan pemerintah daerah. Keputusan untuk pindah agama ke dalam Islam, tidak semata-mata lahir dari hidayah Allah, tetapi ada banyak faktor yang mendasarinya. Faktor-faktor penyebab konversi antara lain: starifikasi sosial, budaya, dan tradisi yang dekat dengan kebiasaan mereka. Faktor budaya yang melekat, pada suku Abun dengan Islam menjadi faktor dominan mereka melakukan konversi. Dalam penelitian diungkapkan, bahwa sebenarnya budaya yang berkembang di masyarakat Abun lebih dekat dengan Islam. Data menujukan: pertama Islam adalah agama yang pertama kali masuk di daerah Tambraw, dibawa oleh Sultan Tidore dari Ternate. kedua faktor guru spiritual yang bertempat tinggal di gunung disakralkan oleh masyarakat setempat. ketiga faktor hidayah dari Tuhan juga menjadi bagian dari konversi agama yang dilakukan oleh komunitas mu’allaf suku Abun. Penelitian ini menggunakan paradigma analisa kritis, serta menggunakan metode kualitatif dengan pendekatan konstruksi sosial. Dengan beberapa informan yang dipilih berdasarkan kategori yang ditetapkan peneliti, terutama mereka yang melakukan ikrar di Kemenag Kab.Sorong. Tekhnik pengumpulan data dilakukan dengan cara wawancara mendalam dengan sejumlah tokoh peniting. Hasil dari penelitian ini menunjukkan perpindahan agama yang dilakukan mu’allaf melalui tiga proses dialektika yakni, secara personal (individual), kelompok degan mengajak keluarga, dan masuk Islam dengan menyembunyikan identitas keislaman. proses perpindahan muallaf yang terjadi berawal dari pencarian jati diri keagamaan, yang mendapatkan masukkan dari lingkungan obyektifnya.
\end{abstract}

Kata kunci: pencarian otentisitas diri, hidayah dan mu’allaf

\begin{abstract}
Converting to a new religion could face a great challenges in Papua. A muallaf, an Islamic term for someone converting his religion to islam, will face a strong reaction from various parties, including local police and government. The decision to convert to Islam is not coming only because of God guidance, there are other underlying factors; which are; social stratification, culture and tradition. However, The dominant factor is The Abun's culture itself that is close to Islamic teachings. Study revealed that the culture that flourished in Abun Society is closer to Islam. Data shows that Islam is the first religion spread in Tambraw region, brought by Sultan Tidore from Ternate. Second, some spiritual teachers that live in mountain considered sacred by the local people. Third, God Guidance. Research used critical analysis, qualitative method with social construction approach. Informants taken by researchers particularly those who took an oath to convert to Islam at MORA Sorong district. Data collected through deep interviews with informants. Research shows that Islamic conversion facilitated through three dialectic processes; personal or individual, group (because of family's influence), and hiding Islamic identity. The process begun by the searching of self religious identity, and then the influence of his/her surroundings.
\end{abstract}

Keyword: authenticity, guidance, muallaf. 


\section{PENDAHULUAN}

$\mathrm{A}$ gama adalah kenyataan terdekat, sekaligus realitas terjauh bagi manusia (Budhy, 1995: v). Agama hadir dalam penampilan yang bermacam-macam, mulai dari ajaran akhlak, hingga ideologi gerakan. Agama, setidaknya berasal dari tiga hal mendasar, yakni etnosentrisme, kompleksitas, dan keragaman. Agama selalu diterima dan dialami secara subjektif, karena itu pula didefinisikan sesuai dengan pengalaman dan penghayatan seseorang terhadap agama yang dianut. Agama merupakan perasaan, tindakan, dan pengalaman individu dalam kesepiannya, sepanjang mereka melihat dirinya berhadapan dengan apa yang dianggapnya sebagai Tuhan (Jalaluddin, 2001:259). Agama sebagai sebuah proses pencarian terhadap 'sesuatu' yang bermakna dan penting (significance). Agama sangat terkait dengan hal yang sakral, dan berkaitan dengan kekuatan besar dan biasanya diasosiasikan dengan Tuhan (the sacred) (Jalaluddin, 2001:20).

Prinsipnya, agama merupakan hak yang berikan Tuhan pada para hambanya untuk menyakini keberadaannya. Di negara kita, telah diatur dalam Pembukan UUD 1945 dari pemekaran Pancasila pada pasal pertama, Ketuhanan Yang Maha Esa. Menurut batang tubuh UUD 1945 pasal 29 yang berbunyi: Negara berdasar atas Ketuhanan Yang Maha Esa. Kemudian pasal berikutnya di sebutkan Negara menjamin kemerdekaan tiap-tiap penduduk untuk memeluk agama masing-masing dan untuk beribadah menurut agamanya dan kepercayaannya itu (UUD 45 dan Amandemennya, 2002:34). Negara menjamin tiap-tiap penduduk untuk memeluk salah satu agama yang ada di Indonesia yang dilindungi oleh undang-undang. Setiap warga negara tidak dipaksakan dalam memilih agama. Secara konstitusional, sepertinya panduan umat beragama sangat ideal dan bersifat normatif. Tetapi di tingkat minoritas, seperti di Kabupaten Sorong, Papua Barat, aturan konstitusi tersebut seolah tidak berlaku, yang berlaku terkadang memaksakan keyakinan mainstream terhadap umat minoritas.

Di sebuah kampung terpencil di Kab. Sorong, terdapat sejumlah komunitas mu'allaf yang dalam sejarahnya berupaya mencari jati diri beragama. Pencarian jati diri, ditempuh dengan beraneka macam rintangan dari masyarakatnya/sukunya sendiri. Rintangan tersebut tidaklah ringan bagi mereka. Tetapi mereka tetap pada pendirian dan keyakinan untuk pindah agama, yakni dari Kristen-Protestan ke Islam. Konversi agama yang mereka lakukan, tidak lain hanya untuk memenuhi panggilan batin yang datang kepada menyapa mereka. Penyiksaan yang dilakukan oleh aparat keamanan ketika itu, seolah tidak dipedulikan. Intervensi dari pemerintah kecamatan di daerah Tambrauw, tidak dihiraukan adanya. Hinaan, caci maki dan kritikan, tidak dipedulikan lagi. Mereka rela meninggalkan daerah asal, serta harta benda mereka di kampung asal, demi memenuhi panggilan suci tersebut. Mereka adalah komunitas suku Abun.

Satu hal yang paling mendasar bagi komunitas ini, bahwa sejarah nenek moyang mereka adalah Muslim. Datangnya Sultan Tidore ke Sausapor membawa berkah tersendiri pada suku Abun tersebut. Menurut tokoh masyarakat Muslim mu'allaf di kampung itu, Sultan Tidore membentuk perkampungan dengan memberi batas patok pada masing-masing pada setiap kampung. Konon masing-masing dari batas patok tersebut sampai sekarang masih bisa ditemui di tengah hutan Tambraw. Sultan Tidore mulanya datang ke suku Abun dengan tujuan menukar kain dengan burung cendrawasih, (masyarakat Abun menyebutnya dengan burung kuning), karena paras dan warna burungnya berwarna kuning. Pada mulanya, Sultan Tidore melakukan pertemuan dengan masyarakat pada suku Abun dan tidak menyampaikan dakwah apa pun. Namun, dengan sikap simpati yang ditunjukkan Sultan, pada akhirnya mereka mengucapkan hormat dengan mengatakan Jo. Bagi suku Abun, kata ini memiliki dua makna, yakni; pertama, sebagai ungkapan untuk meminta keberkahan dari Sultan Tidore yang datang kepada mereka. Kedua, kata Jo berarti satu kesepakatan bulat, bahwa seluruh suku ini menghormati, menjujung tinggi misi agama yang dibawa oleh Sultan ketika itu.

Dakwah yang dilakukan oleh Sultan Tidore, oleh pemuka masyarakat dianggap sebagai batu peletak batu pertama Islam datang di tanah Papua. Dalam perjalanannya, dakwah Islamiyah yang diletakkan oleh Sultan tersebut, tidak berjalan sebagaimana harapan Sultan Tidore dan masyarakat yang telah bersimpati dan ikhlas menerima misi dakwah Islamiyah. Kekosongan dakwah secara intensif menyebabkan mereka tidak mendapatkan pemahaman yang baik dan benar tentang Islam.

Tampaknya, setelah Sultan meninggal, tidak ada penerus yang memperjuangkan misi Islam di daerah tersebut, tetapi secara kultural, masyarakat dan tokoh-tokoh awal suku Abun mengakui, bahwa agama pertama dari nenek moyang mereka adalah 
Islam. Dalam masa kekosongan dakwah tersebut, para penyebar agama lain, masuk dalam kehidupan dan budaya mereka. Maka, ketika datang suku Biak ke Sausapor dengan membawa agama Protestan dari Mansenam Manokwari, oleh C.W. Ottow dan G.J. Geisseir, masyarakat suku Abun yang telah berislam Islam di-Injilkan secara massal dengan menggunakan bahasa Biak. Suku Biak ini, berasal dari daerah kepulauan yang sangat jauh di ujung timur pulau Papua. Suku Biak ini, bagi mereka adalah suku yang kejam dan sadis. Di bawah alam sadar, suku Abun mengaku secara umum (comman sence), bahwa suku Biak seringkali menindas suku lain yang tidak seiman dan sekeyakinan dengan mereka. Dengan bergulirnya waktu dan ditopang oleh SDM yang cukup di kalangan mereka, perkembangan agama Kristen semakin tampak jelas. Banyak anggota masyarakat dari suku Abun beragama Kristen Protesten dan mulai meniggalkan kepercayaan dan budaya asal mula nenek moyang mereka.

Di tengah berlangsungnya proses misionaris tersebut, terdapat sejumlah komunitas tertentu yang kembali tertarik kepada Islam. Mereka secara diam-diam bersimpati kepada Islam. Mereka yakin, bahwa agama yang pertama yang datang ke Tanah Papua, khusunya di kepala burung adalah Islam. Menurut ingatan tokoh Muslim, bernama Imam Sangaji, agama yang pertama masuk di Kabupaten Tambrauw adalah Islam. Islam yang berkembang di Suku Moi Karon berasal dari penyebaran agama yang dibawa oleh Sultan Tidore dari Maluku. Mereka mencari tahu lebih banyak informasi tentang Islam. Pada tahun 1991 komunitas suku Abun menyatakan diri berislam secara kolektif. Jumlah mereka sekitar 169 orang. Menurut H.Tejo, bahwa orang tua dari Imam Sangaji ini, telah dahulu memeluk agama Islam dan bertemu langsung dengan Sultan yang ketika itu mulai berdakwah di daerah kepala Burung, tepatnya di Kab. Tambrauw saat ini. Tradisi tutur yang berkembang di masyarakat ketika menyebutkan, bahwa ketika Sultan Tidore memasuki daerah ini, terjadi musibah yang kemudian menyebabkan tenggelamnya perahu yang ditumpangi oleh Sultan dan anak buahnya. Menurut informasi, Kitab Alquran tersebut tenggelam di lautan kemudian terapung, sehingga ada orang yang klaim mengambilnya. Kitab suci tersebut diyakini berasal dari cetakan Istambul yang ketika itu masih berukuran besar (Haji Tejo, wawancara 14/3/ 2014). Pada mulanya mereka bersedia akan disunnat secara masal dari tokoh-tokoh agama Islam yang akan datang dari kota Sorong ketika itu. Istilah sunat dalam pemahaman komunitas mu'allaf tersebut adalah menyerahkan diri kepada agama Islam dan meyakini kebenarannya. Istilah ini sebanding dengan makna bersyahadat. Sebenarnya, istilah ini harus diluruskan oleh pemuka agama, khususnya MUI dan Kemenag guna mencapai makna yang benar. Sunat bukan bersyahadat sebagai simbol dari masuknya seseorang ke dalam Islam.

Menariknya, masyarakat suku Abun yang akan berpindah agama Islam pada tahun tersebut mengalami perlawanan serius dari suku yang mayoritas umat beragama Protestan. Dengan peristiwa itu, kemudian terjadilah kekacauan, bahkan peperangan di antara mereka. Komunitas mu'allaf ini tetap berjuang untuk mempertahan keyakinan barunya, walaupun mendapat intimidasi. Mereka bahkan melakukan peperangan antar suku mereka sendiri yang belum bersedia menganut agama Islam.

Masyarakat suku Abun yang aslinya berdomisili di daerah pemekaran Kabupaten Tambrauw, tepatnya di Sausapor, dengan gigihnya mempertahankan keyakinannya. Dalam kondisi seperti itu, komuntias mu'allaf dari suku Abun meninggalkan tempat kelahirannya dan membuat perkampungan di bendungan SP satu dan Klalin satu dan berbagai tempat lain di kota dan kabupaten Sorong.

Konversi agama merupakan proses dinamis yang tidak sederhana dan termediasi melalui orang lain, institusi, komunitas, dan kelompok tertentu. Fenomena konversi agama tersebut, tentu tidak hanya membawa konsekuensi personal, tetapi reaksi sosial yang beraneka ragam di masyarakat. Terutama dari pihak keluarga dan komunitas terdekat mereka. Kasus konversi agama di komunitas mu’allaf di Kab. Sorong tersebut, tampak jelas adanya perubahan psikologi sosial, misalnya penghentian dukungan secara finansial, kekerasan secara fisik maupun psikis, hinaan, pengucilan, bahkan pengusiran dari kampung halaman kerap dialami. Jalinan aqidah sepertinya lebih dominan mempengaruhi kehidupan komunitas mu'allaf tersebut.

Dilema dan konflik seringkali dialami oleh para mu'allaf, ketika dihadapkan dengan pelbagai keputusan penting secara bersamaan, misalnya saat harus memilih agama yang diyakini, atau meninggalkan orang tua dan keluarga yang dicintai. Risiko-risiko ini dibayar mahal oleh komunitas mu'allaf yang mencari jati diri mereka dalam beragama. Sementara mu'allaf dari suku Abun dan 
lingkungan sosial mereka, menganggap pindah agama sebagai upaya memberontak terhadap otoritas dan lingkungan sosial. Dalam ruang hidup inilah, komunitas berhadapan dengan realita yang tentunya dapat menimbulkan a sense of crisis dalam batin. Krisis merupakan tahap yang dapat menjadi daya utama terjadinya perubahan yang dihadapi.

Komunitas mu'allaf dari suku Abun tersebut, tampaknya telah terjadi penguatan perasaan dan identifikasi terhadap sesuatu yang sakral. Penguatan dan keterhubungan dengan objek yang sakral paling tidak meliputi tiga aspek: Pertama, kekuatan spiritual (spiritual conversion). Konversi tipe ini didorong oleh kekuatan spiritual, individu mengidentifikasikan diri dengan sesuatu yang dianggap Ilahi. Kedua, kelompok religius (Religious group conversion). Konversi ini, biasanya terjadi pada individu yang terlibat pada sekte, gerakan keagamaan baru, atau gerakan mistis tradisional. Ketiga, nilai-nilai kemanusiaan (whole of of humanity, universal conrversion) (Pargament, 2000:146). Konversi jenis ini, lebih merujuk pada nilai-nilai kemanusiaan secara umum.

Dari ketiga unsur yang sakral tersebut, komunitas mu'allaf di Kab. Sorong tampaknya lebih didasari oleh faktor pertama, yakni penguatan spiritual dalam pengidentifikasian diri kepada Tuhan Yang Maha Segalanya. Komunitas mu’allaf tersebut menyadari bahwa dari sekian banyak agama yang ada di muka bumi, pastilah ada satu agama yang paling benar dan lurus. Tidaklah mungkin alam semesta ini mempunyai banyak Tuhan yang dipercaya oleh agama Kristen sebelumnya.

Berdasarkan eksplorasi di atas, ketertarikan dan permasalahan yang ada dalam penelitian ini, akan fokus pada tiga aspek mendasar yakni: apa saja faktor-faktor penyebab konversi agama pada komunitas muallaf di Kabupaten Sorong? Bagaimana proses konversi yang dilakukan oleh komunitas mu'allaf di Kabupaten Sorong? Dan bagaimana dampak psikologi yang dialami pra dan pasca konversi? Penelitian ini dilaksanakan untuk mengeksplorasi, memahami faktor-faktor penyebab konversi agama, proses dan kronologi konversi agama yang dilakukan oleh komunitas mu'allaf di Kab. Sorong.

Penelitian ini dapat menjadi referensi dari faktor-faktor apa saja yang dominan dalam konversi agama bagi masyarakat luas. Dari proses konversi agama dan hal-hal yang mempengaruhinya, idealnya ada pola-pola khusus yang dilakukan oleh pihak terkait, termasuk pemerintah daerah untuk memberikan pembinaan mereka. Hasil penelitian ini, nantinya diharapkan dapat menjadi rekomenasi ilmiah kepada MUI dan Kemenag untuk lebih serius melihat komunitas mu'allaf di Kab. Sorong.

Secara teoritis, penelitian ini diharapkan dapat memperkaya dan mengembangkan penelitian di bidang psikologi agama dalam memberikan informasi mengenai proses pencarian otentisitas diri secara otonom. Manfaat praksis bagi lembagalembaga keagamaan terkait, termasuk MUI dan Kantor Kemenag Kabupaten, agar dapat memberikan perhatian serius kepada masyarakat mu'allaf. Manfaat bagi subjek, diharapkan dapat memberikan informasi mengenai proses pencarian otentisitas diri dalam melakukan konversi agama tertentu. Subjek diharapkan mampu mengatasi berbagai perubahan yang terjadi dengan efektif dan bermakna. Sedangkan bagai masyarakat luas, penelitian ini diharapkan dapat menambah pengetahuan dan wawasan di bidang psikologi agama, khususnya mengenai pencarian otentisitas (jati diri) dalam kehidupan beragama.

\section{Tinjauan Pustaka}

Harus diakui, beragama adalah hak asasi dasar manusia (Ahmad, 2000: 67). Agama merupakan sebuah entitas yang muncul pada tingkat sosial yang melibatkan afiliasi dan kohesifitas kelompok dan pranata sosial (Jalaluddin, 2001:20-23). Keputusan subjektif yang dibuat oleh individu berkaitan dengan agama, misalnya konversi agama, tidak bisa menghindari dari efek sosial yang akan muncul. Dalam upaya mengeksplorasi kesadaran dan pengalaman-pengalaman subjektif manusia, terutama yang berkaitan dengan konversi agama di komunitas mu'allaf di Kab. Sorong, maka dalam penelitian ini menggunakan dua pendekatan utama, yakni sosio-epistimologi dan fenomenologi.

Pertama, pendekatan sosio-epistimologi teori pengetahuan yang berwatak sosial. Ciri pendekatan ini adalah berpikir inovatif dalam menyingkap berbagai kemungkinan, baik dalam akal maupun dalam pengalaman, serta menata dan menguji argumen untuk menumbuhkan aktivitas dengan rasio dan nalar sosial sebagai tugas insani. Rasionalitas sejati tidak tertutup untuk dirinya sendiri, tetapi rasio manusia harus berwatak sosial dengan kepentingan-kepentingan manusia dalam lingkungan sosial yang khas (Qatloly, 2013:3). Tujuan dari pendekatan ini adalah untuk menujukkan adanya visi baru tentang hakikat pengetahuan dan keilmuan yang terpancar dari 
ruang kedalaman hati dan hidup manusia (inner vision). Visi tersebut menunjukan adanya pertautan yang bersifat batiniyah antara hakikat pengetahuan dan masyarakat manusia itu sendiri. Dalam konteks penelitian ini, penulis ingin melihat gejala konversi agama yang dilakukan oleh komunitas mu'allaf pada masyarakat lokal pribumi di Kab. Sorong dan sekitarnya. Pendekatan ini menjadi penting di kedepankan guna mencari dan mengukap kebenaran yang terjadi pada komunitas tersebut. Artinya, bahwa pengetahuan tidak lahir dari ruang kosong, tetapi selalu bercengkrama dengan masyarakat dan manusia di sekitarnya, demi kepentingan memanusian diri (humanisasi dan emansipasi) serta kesejahteraan.

Pendekatan sosio-empistimologi berupaya mengembangkan sebuah sistem pengetahuan berkarakter sosial dalam rangka praksis yang mendorong tindakan-tindakan emansipatif, (pembebasan), demi tugas pencerdasan, humanisasi, cinta kasih, dan kesejaheteraan hidup manusia (Qatloly, 2013:5-7). Sosio-epistimologi menyediakan sebuah refleksi kritis, radikal dan komprehensif atas pengetahuan untuk menyingkap segala realitas yang terjadi dalam konversi di komunitas mu'allaf tersebut.

Kedua, Fenomenologi. Fenomenologi secara etimologi berasal dari dua kata bahasa Yunani, yaitu phenomenon dan logos. Dari sudut bahasa, istilah phenomenon diartikan sebagai penampilan, sesuatu yang menampilkan diri. Fenomenologi, di samping sebagai pendekatan, juga bisa dipakai sebagai metode yang bisa membantu untuk mendekati gejala, bagaimana menghayati, menghidupi, atau mengalami gejala yang sebenarnya (Abidin, 2002:69).

Pendekatan fenomenologis mendiskripsikan makna pengalaman subjek akan fenomena yang sedang diteliti. Fenomenologi berusaha memahami manusia dari segi kerangka berpikir maupun bertindaknya sebuah objek. Hal terpenting dalam penelitian fenomenologi, kenyataan yang terjadi sebagaimana yang dibayangkan (dipikirkan) oleh individu-individu itu sendiri (Moleong, 2004:35). Husserl memahami fenomenologi sebagai suatu analisis deskriptif, serta introspektif mengenai kedalaman dari semua bentuk kesadaran dan pengalaman langsung, seperti religius, moral, estetis, konseptual, serta indrawi (Bagus, 2000:236).

Penelitian dengan pendekatan fenomenologi berusaha mengungkap esensi dan makna terdalam dari pengalaman-pengalaman subjek tertentu.
Pendekatan fenomenologi, mengacu pada perspektif mengembangkan suatu bidang fenomenologi transendental yang berdasar pada konsep Husserl. Pendekatan fenomemologi Husserl, lebih menekankan pada penyingkiran prasangka (epoche atau bracketing). Husserl menekankan empat hal dalam penelitian fenomenologi, yaitu: 1) Peneliti mencari makna inti (essence/invariant structure) pada suatu fenomena atau apa yang dialami subjek. 2) Penelitian fenomenologis menekankan intensionalitas kesadaran (intentionality of conscioucness) di mana kesadaran akan sesuatu selalu bersifat intensional atau mengarah pada sesuatu, sehingga realitas suatu objek hanya dilihat menurut makna pengalaman pada individu. 3) Analisa data fenomenologi melalui beberapa langkah, yaitu reduksi data, menganalisis kata-kata kunci dari pernyataan subjek, serta mencari makna yang mungkin muncul di belakangnya. 4) Peneliti menyingkirkan semua prasangkanya tentang fenomena yang diteliti, hal ini oleh teori Husserl disebut epoche, (artinya meletakkan dalam kurung) atau bracketing (melepaskan diri) (Bagus: 2000:237). Dengan demikian, peneliti mampu bersikap netral dan memahami subjek dalam dunianya.

Di samping itu, untuk analis dalam penelitian ini menggunakan teori sosiologi, yakni interaksionalisme simbolik. Teori ini berasumsi, bahwa manusia dipengaruhi oleh penafsiran atau pemaknaan terhadap simbol-simbol berdasarkan kesepakatan bersama (Fisher, 1989:77). Manusia bertindak terhadap benda (baca: objek) berdasarkan arti yang dimilikinya. Esensi interaksi simbolik adalah aktivitas yang berciri khas manusia atau pertukaran simbol yang diberi makna (Mulyana, 2001:68). Teori interaksi simbolik menekankan pada hubungan antara simbol dan interaksi, serta inti dari pandangan pendekatan ini adalah individu. Definisi singkat dari ke tiga ide dasar dari interaksi simbolik, antara lain: (1) Pikiran (Mind) adalah kemampuan untuk menggunakan simbol yang mempunyai makna sosial yang sama, di mana tiap individu harus mengembangkan pikiran mereka melalui interaksi dengan individu lain, (2) Diri (Self) adalah kemampuan untuk merefleksikan diri tiap individu dari penilaian sudut pandang atau pendapat orang lain, dan teori interaksionisme simbolis adalah salah satu cabang dalam Banyak ahli di belakang perspektif ini yang mengatakan bahwa individu merupakan hal yang paling penting dalam konsep sosiologi (Bustanuddin, 2005:1-2). Dalam banyak kajian, agama dikatakan berfungsi sebagai 
suatu sistem nilai yang memuat norma-norma tertentu (Jalaluddin, 2001:32-33). Secara umum, norma-norma tersebut menjadi kerangka acuan dalam bersikap dan bertingkah laku agar sejalan dengan keyakinan agama yang dianulnya. Sebagai sistem nilai, agama memiliki arti yang khusus dalam kehidupan individu/komunitas, serta dipertahankan sebagai bentuk yang khas. Ada berbagai faktor yang mendorong seseorang beragama.

Menurut Hardjana (1992:45) paling tidak ada enam faktor utama yang menyebabkan seseorang beragama atau pindah agama (konversi). Pertama, dalam kehidupan manusia menghadapi banyak malapetaka dan marabahaya. Manusia beragama untuk mendapatkan keamanan dari marabahaya dalam hidupnya. Kedua, manusia mengalami ketidakpastian, serta tidak menemukan sesuatu yang sungguh-sungguh dapat diandalkan. Dengan beragama, manusia berharap dapat menemukan sosok yang dapat diandalkan. Ketiga, manusia ingin mendapatkan jawaban-jawaban atas pertanyaanpertanyaan fundamental, misalnya asal manusia, tujuan hidup, hal-hal yang terjadi sesudah kematian. Dengan beragama, manusia berharap mendapatkan kejelasan atas pertanyaan-pertanyaan yang berkaitan dengan misteri kehidupan. Keempat, manusia beragama supaya dapat melaksanakan, melestarikan, dan mengembangkan praktikpraktik kehidupan yang baik. Kelima, manusia beragama untuk mendapat kekuatan, dorongan, dan pemantapan dalam pelaksanaan nilai-nilai kehidupan. Keenam, manusia dalam hidupnya memiliki kerinduan akan Tuhan. Dengan demikian, orang menganut agama, hendak memperoleh pemuasan akan hasratnya yang paling dalam, yaitu menemukan Tuhan sendiri dalam diri mereka. Iman berarti kepercayaan kepada Tuhan yang teguh dan mengandalkan Tuhan sebagai sandaran hidup. Hardjana dalam bukunya menyebutkan iman ekstrinsik sebagai iman demi kepentingan pribadi yang bersangkutan.

Dalam konteks penelitian lokal di lapangan, sebelumnya dilakukan oleh Saudari Indria Noor, tentang "Eksistensi dan Fungsi Suku-suku di Kota dan Kab. Sorong”. Penelitian ini banyak mengeksplorasikan betapa kuatnya pengaruh unsur-unsur primordialisme masyarakat di kota ini. Dari hasil penelitan sebelumnya, ditemukan interaksi suku-suku yang ada di kota dan Kab. Sorong secara sederhana relatif kondusif, walapun terdapat beberapa ketegangan yang terselubung di antara mereka, seperti yang terjadi beberapa bulan sebelumnya, yakni di mana salah seorang dari suku Bugis berkelai dengan suku Ambon yang kemudian menyebabkan kematian. Faktor-faktor yang menyebabkan terjadinya interaksi antar suku, tidak hanya dilatar belakangi oleh kekerabatan semata, tetapi oleh ikatan emosional agama, hubungan kerja (profesi) dan nasib sepenanggungan.

Demikian pula penelitan yang dilakukan oleh Muhammad Abbas, tentang suku Kokoda, melihat fenomena masyarakat dari aspek pendidikannya yang terbilang sangat terbelakang. Dalam kondisi yang demikian itu, pola kehidupan masyarakat Kokoda tersebut menjadi tuan di rumah sendiri. Pendekatan yang dilakukan oleh Peneliti, berupaya mendekatinya secara sosiologis, yakni pendekatan teori Webber tentang teori Undertanding.

Dari aspek yang lain, Mujahidah dalam salah satu penelitiannya, melihat masyarakat suku Moi dari aspek Gender. Penelitian tersebut, menemukan bahwa posisi laki-laki, dalam hal ini suami, berada pada puncak menara gading, sementara perempuan (istri), harus bekerja lima kali lipat dari kaum laki-laki. Bias gender yang ditemukan di suku Moi tersebut memposisikan kaum perempuan hanya sebagai objek penderita dari kaum lakilaki. Pendekatan yang dipakai oleh peneliti adalah analisis diskriptif. Demikian pula penelitian yang dilakukan oleh peneliti sebelumnya, tentang potensi konflik yang terjadi di kota Sorong tidak membahas dan menyentuh sedikitpun persoalan komunitas mu'allaf tersebut.

Berdasarkan hasil studi-studi tersebut, apa yang akan diteliti nantinya tidak mempunyai relevansi dengan objek yang akan diteliti sebelumnya. Penelitian ini akan diarahkan untuk melihat bagaimana proses konversi komunitas mu'allaf di Kab. Sorong dalam mencari jati dirinya mereka sesungguhnya. Penelitian ini memfokuskan diri pada tahapan dan dampak psikologis yang dialamai oleh komunitas mu'allaf pra dan pasca konversi.

\section{METODE PENELITIAN}

Penelitian ini merupakan penelitian kualitatif. Sebagai tradisi dalam ilmu sosial, penelitian ini bergantung pada pengamatan pada manusia sendiri yang selalu berhubungan dengan orang-orang (baca: subjek) dalam bahasanya dan peristilahannya (Moleong, 2004:151). Fokus penelitian ini, bagaimana melihat, memahami latar belakang, peranan, proses dan pengaruh konversi agama terutama terhadap pencarian otentisitas diri di suku 
Abun yang melakukan konversi agama. Kriteria subjek yang digunakan dalam penelitian ini antara lain: (1) Sekelompok masyarakat memeluk Islam secara serentak sejak mengikrarkan syahadat dan melakukan hitanan. (2) Masyarakat dari suku Abun, baik itu dalam jumlah keluarga, baik laki-laki maupun perempuan.

Teknik pengumpulan data dilakukan dengan wawancara langsung kepada sejumlah kelompok, informan dan komunitas yang terlibat dalam konversi agama tersebut. Adanya komunitaskomunitas tertentu, sedikit banyak saling mempengaruhi satu sama lain. Hasil wawancara dengan sejumlah kalangan tersebut, diharapkan dapat mengumpulkan data terkait dengan proses konversi agama. Yang dilakukan oleh komunitas mu'allaf dari suku Abun tersebut. Wawancara dengan tokoh-tokoh agama dan data dari pemerintah juga dilakukan sebagai data pendukung.

Teknik lain dalam menggali data adalah dengan observasi. Observasi ini dilakukan untuk mengambil data yang terkait dengan hal-hal sebagaimana dalam wawancara. Fokus dari observasi ini adalah mengamati tindakan-tindakan dalam suku-suku yang terkait dengan dominan melakukan konversi serta kelompok-kelompok tertentu yang disinyalir saling mempengaruhi konversi agama. Demikian pula catatan lapangan. Catatan lapangan tentang apa yang didengar, dilihat, dialami, dan dipikirkan dalam rangka pengumpulan data dan refleksi terhadap data dalam penelitian kualitatif (Moleong, 2004:153). Catatan lapangan dibuat dalam bentuk deskripsi dan dilakukan segera setelah observasi dan interview dilakukan. Tahapan terakhir adalah analisis data. Moleong mendefinisikan analisis data sebagai proses mengorganisasikan dan mengurutkan data ke dalam pola, kategori, dan satuan uraian dasar, sehingga dapat ditemukan tema dan bisa dirumuskan hipotesis kerja, seperti yang disarankan oleh data. Usaha untuk memperoleh data yang lebih tajam terhadap data hasil temuan di lapangan, dilakukan dengan menggunakan beberapa teknik analisis data kualitatif. Maka, dengan pendekatan sosio-epistimologi dan fenomenologi diharapkan mampu untuk menganalisis data secara cermat.

Beberapa teknik data, khusus yang dipakai dalam penelitian kualitatif, meliputi: (1) Peneliti membuat dan mengatur data yang sudah. (2) Peneliti membaca dengan teliti data yang sudah peneliti mendeskripsikan pengalamannya di lapangan. (3) Horisonalisasi pada tahap ini, transkrif wawancara akan diperiksa lagi untuk mengetahui pernyataan yang relevan dan tidak relevan bagi penelitian ini. Tahap ini, bisa dilakukan dengan cara menandai bagian pernyataan yang relevan dan menuliskannya pada kolom yang terpisah.

Analisis data merupakan upaya mencermati dan mensistematikakan data-data yang diperoleh melalui wawancara, observasi maupun telaah catatan penting di lapangan. Analisis dalam penelitian ini, dilakukan melalui dua tahap, yaitu selama di lapangan dan setelah dari lapangan. Analisis di lapangan ditempuh dengan mempersempit fokus, menetapkan tipe studi, mengembangkan pertanyaan analitik, menyusun komentar, dan telaah kepustakaan yang relevan.

\section{PEMBAHASAN}

\section{Faktor Penyebab Konversi}

Panggilan batin dari Tuhan, seringkali dimediasi oleh hal-hal di luar jangkaun pikirian manusia. Komunitas mu'allaf yang berasal dari Sausapor, dan sekarang berdomisili SP satu dan Klalin di Kab. Sorong disebabkan oleh beberapa faktor, di antaranya adalah faktor, sosial, budaya, adanya tokoh spiritual, dah hidayah Tuhan kepada sejumlah tokoh adat pada suku tersebut.

\section{Faktor Sosial}

Agama mencakup kehidupan secara pribadi dan hubungan sosial. Dalam penelitian ini, penulis menemukan hal yang menarik berkaitan dengan proses pengambilan keputusan. Dalam proses pengambilan keputusan tersebut, terdapat faktor penghambat dari lingkungan sosial mereka sendiri. Hal ini menimbulkan satu pertanyaan baru, seberapa jauhkah peran keluarga dan lingkungan sosial dalam pengambilan keputusan berpindah agama? Karena, manusia, selain sebagai makhluk pribadi, juga makhluk sosial. Hal ini semakin menarik bila dilihat dari kehidupan suku-suku di pedalaman Sausapor, Kab. Tambrauw.

Pengaruh sosial adalah pengaruh kebiasaan rutin dalam sebuah komunitas. Pengaruh kebiasaan rutin dapat mendorong seseorang atau kelompok untuk berubah kepercayaan. Jika dilakukan secara rutin, hingga terbiasa. Keberadaan masyarakat mu'allaf dari suku Abun sangat terpinggirkan dari suku Biak yang hidup di tengah-tengah mereka. Suku Biak menganggap mereka sebagai komunitas yang tidak berguna. Keberadaan mereka tidak diperhitungkan secara sosial di masyarakat. Jika suku Abun beribadah di gereja mereka, selalu diejek dan dicemoh, sehingga mereka merasa minder 
dengan sikap orang-orang dari suku Biak yang sombong. Maka, ketika mereka beribadah, selalu saja berada di posisi paling belakang, bahkan di luar gereja (H. Tejo, wawancara 12/10/2013).

Konflik batin yang dialami oleh suku muncul rasa bersalah dan ketidaknyamanan menjalankan agama Kristen (Protestan). Faktor emosi lebih menonjol dalam proses perpindahan agama secara spontan. Perpindahan agama yang spontan lebih dikarenakan faktor afeksi, seperti ketidaknyamanan mereka secara sosial dalam agama mereka sendiri. Akibat perlakuan mereka terhadap suku Abun ini, ternyata berdampak serius kepada batin dan emosi komunitas mu'allaf ketika itu. Maka dari sini, muncul kesadaran akan hakikat agama yang benar. Dalam pikiran komunitas mu'allaf tersebut, mana ada umat beragama yang perilakunya seperti itu kepada sesama jamaah (baca: umat). Secara ekplisit suku Abun melakukan konversi karena masalah sosial keagamaan antara suku Abun dengan suku Biak. Ketidaknyamanan mereka menjalankan ibadah di gereja bersama suku lain.

Mereka temukan ketenangan dan kedekatan terhadap Tuhan melalui Islam. Meskipun pengambilan keputusan ini bersifat komunitas, tetapi tidak lepas dari hambatan, dukungan sosial, peran key person, dan munculnya fenomenafenomena yang mendukung keputusan tersebut. Di sinilah dapat dikatakan bahwa, pergaulan sosial antar pemeluk agama yang sama, atau berbeda dapat memberikan insentif, berupa pengetahuan dan informasi baru kepada mereka, yang kemudian berpengaruh terhadap religiusitasnya, sehingga menuntun mereka kepada terjadinya pindah agama.

\section{Faktor Budaya}

Pengaruh lain yang menyebabkan konversi adalah faktor budaya. Umumnya, budaya, seperti peninggalan-peninggalan zaman dahulu, seperti beragam makanan atau pun benda-benda lainnya. Begitu pula dengan suku Abun, peninggalan sejarah yang berbau Islam masih tampak dalam kehidupan mereka. Adanya sejumlah nama marga yang diberikan oleh tokoh awal ketika mereka mengenal Islam. Nama-nama marga tersebut antara lain: marga Sidiq, marga Aisyah, marga Sufi dan marga Najasi.

Selain itu, menurut keyakinan umat Islam di daerah itu, bahwa pada masa penyebaran agama Islam yang dibawa Sultan Tidore meninggalkan jejak sejarah yang selama ini belum banyak diketahui oleh masyarakat Papua. Peninggalan ini, berupa patok kayu yang berdiri tegak dengan ukuran $\pm 100 \mathrm{~cm}$. panjang dan lebar $\pm 5 \times 10 \mathrm{~cm}$. Bukti sejarah ini, mengungkapkan bahwa agama yang masuk pertama kali di Kepala Burung Papua adalah agama Islam yang dibawa oleh Sultan Tidore pada abad 17. Sultan Tidore menancapkan patok pada saat dilantiknya para kepala magra dan tokoh adat di daerah tersebut.

Sultan Tidore membagi wilayah kepada empat marga antara lain: marga Yenbra, Yenjau, Yengre, dan Yeblo. Saat ini, masyarakat suku Abun hanya mengenang setiap tahun, tepatnya pada bulan puasa. Sebagian masyarakat suku Abun menyempatkan pergi melihat patok dan tembok tersebut untuk mengenang masa dulu dan diceritakannya kepada anak cucu mereka. Menurut kepala suku Yenjau, Sultan Tidore adalah hamba pilihan Allah yang biasa disebut dengan Waliyullah. Seperti yang diceritakan informan. (H. Lukman Yenjau, wawancara 7/10/ 2013), Sultan Tidore adalah seperti Wali Songo, Sultan Tidore menanam patok yang bersejarah, bukan dengan tangannya, melainkan dengan kekuatan gaib yang dimilikinya. Istilah, rohnya yang berjalan menuju ke hutan, lalu menanam patok tersebut. Patok yang ditanam oleh Sultan Tidore bukan sembarang patok, tetapi patok yang punya makna. Setelah tokoh tersebut masuk Islam, baru menyadari mengerti maksud patok yang di tanam Sultan Tidore. Ada dua makna patok bagi suku Abun, pertama patok itu menunjukkan bahwa Islam telah hadir sebelum agama lain masuk di daerah tersebut. Kedua, dengan adanya patok tersebut berarti telah dikuasainya daerah tersebut oleh masyarakat asli suku Abun. Dengan dua makna tersebut, masyarakat suku Abun dan tokoh kunci suku berkeyakinan, bahwa suatu saat nanti masyarakat Islam akan menguasai dan berjaya di Tanah Sasapor Tambraw.

Selain itu, faktor budaya yang menyebabkan koversi adalah pertama, makan babi. Tradisi makan babi bagi umat Kristen adalah sebagai salah satu yang wajar terjadi. Karena agama ini tidak diatur secara detail batasan-batasan tertentu bagi umatnya. Beda halnya dengan Islam. Tetapi dalam hati mereka sudah tertanam suatu keyakinan bahwa dalam Islam tidak diperbolehkan. Komunitas mu'allaf di Kab. Sorong dan sekitarnya, ketika itu tidak merasa senang dengan daging babi yang dimakan oleh umat Kristen tersebut. Tradisi ini, bagi komunitas mu'allaf, sebagai salah satu tradisi buruk dan memuakkan. Dengan demikian, faktor kebiasaan memakan daging bagi menjadi pemicu hijrahnya mereka ke Islam. Sebagain dari suku Abun yang sangat takut 
dengan tokoh agama dan oknum pemerintah daerah itu, memilih untuk pindah agama dari Kristen Prostestan ke gereja Advent. Karana umat dari jenis aliran dalam Kristen ini tidak memakan babi dan anjing sebagaimana Protestan. Kedua, makan anjing. Anjing bagi mereka adalah binatang yang menjijikan. Keberadaan binatang tersebut menjadi benalu dalam beraktivitas. Mereka percaya, makanan anjing secara kebersihan mencerminkan agama itu sendiri. Dari perilaku dan kebiasan sukusuku Biak yang memakan anjing, menjadi penilain tersendiri bagi para mu'allaf yang hendak pindah agama. Dalam pengamatan penulis, ketika berada di lokasi penelitian menujukkan bersihnya rumah dan lingkungan mereka dari dua jenis binatang tersebut. Mereka parcaya Tuhan itu bersih dan mencintai kebersihan.

Suku Abun sedikit demi sedikit meninggalkan budaya yang tidak sesuai Islam. Segala sesuatu yang bertentangan dengan Islam mereka tinggalkan. Suku ini dalam setiap acara-acara tidak menyajikan makanan-makanan yang dilarang oleh agama Islam. Pada tradisi Moi Karon, setiap ada acara masyarakat tersebut memakan anjing atau babi, itu sudah menjadi keharusan bagi mereka. Setelah suku Abun beragama Islam, di mana mereka tinggal tidak mengkonsumsi anjing dan babi, bahkan mereka merasa geli melihatnya. Sesuai dengan yang dituturkan Hamidah Yenjau yakni: "kami sebelum masuk Islam memakan anjing dan babi itu sudah merupakan tradisi. Biasanya pada setiap ritual/acara makanan yang utama adalah anjing dan babi. Tapi setelah kami Islam, tidak memakan anjing dan babi bahkan kami geli melihatnya (wawancara, 6/10/2013). Ketiga, tradisi minuman keras. Kebiasaan masyarakat lokal dari suku apa pun adalah mabuk-mabukan. Kebiasaan ini, menurut para mu'allaf adalah pekerjaan yang mubazzir dan sia-sia. Tradisi ini, bagi agama yang benar, tentu akan dilarang. Tetapi dalam agamanya orang-orang suku Biak, seolah tidak dihiraukan. Kebiasaan mereka mabuk-mabukan pada dasarnya kebiasaan umat yang tidak terpuji dan pengotor. Dampak dari perbuatan tersebut pun tidak sedikit. Biasanya, sekelompok orang setelah mabukmabukan akan berbuat kekacuan bagi orang lain dan lingkungannya. Kondisi seperti ini, tampaknya tidak menyehatkan orang dan lingkungannya. Dalam pemahaman mereka, di agama Islam, perbuatan mabuk-mabukan dilarang karena membawa dampak negatif bagi diri sendiri dan lingkungannya. Seiring dengan itu, kecenderungan kepada Islam secara bertahap mulai tertanam dalam batin mereka.

Setelah komunitas tersebut menyatakan diri berislam, tradisi yang berkembang pada suku Abun pada saat ini, adalah ritual gunting rambut dan pemberian nama pada anak cucu mereka, yakni memakai cara-cara Islam. Pada setiap kelahiran, anak sudah membudaya Islam dalam diri suku Abun dengan memperdengarkan azan dan komat pada telinga kanan dan kiri pada anak yang baru lahir. Pemberian nama dengan mengundang tetangga terdekat untuk membacakan tahlil dan shalawat pada saat pengguntingan rambut anak yang baru lahir.

\section{Adanya Tokoh Spiritual}

Dalam konversi agama yang dilakukan komunitas mu'allaf suku Abun, diyakini bahwa tokoh-tokoh mereka dibimbing oleh sesorang yang bertempat tinggal di atas gunung Tambrauw. Sang tokoh tersebut, diyakini memiliki kekuatan supranatural. Tokoh spiritual itu, seperti diceritakan oleh salah satu kepala suku ini, bahwa orang suci yang bertempat tinggal di puncak gunung Tambraw (Lukman alias Amos, wawancara 5/10/2013). Menurut informan, bahwa hanya ada empat orang yang diizinkan naik atas gunung yang sakral tersebut. Selain empat orang ini, tidak diizinkan. Kalau pun ada orang lain yang mencoba mendaki ke atas gunung tersebut, maka, akan terjadi hal-hal yang tidak diinginkan. Bukan saja bahaya yang akan ditemui, tetapi bencana akan menimpa kehidupan mereka. Ke empat orang itu adalah: Amos (Haji Lukman), Darwin, Yakob, dan Yunus Kaulan. Ke empat juru kunci gunung ini, tiga di antaranya masih hidup dan tokoh yang paling senior, Yunus Kaulan telah meninggal dunia sebelum menyatakan diri masuk Islam. Tokoh spiritual tersebut diyakini oleh para juru kunci dapat memberikan bimbingan dan nasehat, baik secara langung dengan mendatangi gunung sakral tersebut atau pun secara tidak langsung melalui kontak batin. Di sini, dapat dikatakan pengetahuan religius tidak hanya didapat melalui orang tua atau keluarga, tetapi melalu jalur lain yang tidak biasa ditempuh. Dalam konteks suku ini, tampaknya seseorang yang dianggap suci dapat membimbing mereka secara rohani melalui caracara dan waktu-waktu tertentu.

\section{Hidayah Tuhan}

Seorang pelaku konversi dapat pula dipengaruhi karena faktor hidayah Ilahi. Mereka merasa bahwa dirinya terlahir kembali. Ketika 
jiwanya sudah merasa tentram dengan suatu keyakinan yang sudah didapatnya, maka akan menjalankan syariat Islam dengan sungguhsungguh. Kisah yang dialami oleh Amos dan kawan-kawan, ketika awalnya memilih agama baru sebagai jalan hidup, tampaknya mengantarkan mereka kepada gerbang Islam.

Agama yang berkembang pada komunitas mu'allaf suku ini, umumnya adalah orang-orang sederhana dan rendah hati. Hidayah Allah, ternyata menghampiri mereka. Di saat kondisi sosial budaya yang tidak memihak dengan mereka, pada saat yang sama, Allah memberikan mereka jalan kebenaran sesungguhnya. Allah tidak, tampak dalam pandangan zahir manusia, tetapi tampak di hati batin para hamba-NYA. Seandainya Allah menampakkan diri di hadapan manusia, maka manusia yang menyaksikannya akan terkapar, karena tidak mampu menahan kekuasaannya. Seperti yang dituturkan oleh informan sebagai berikut: "Kami masuk Islam bukan karena paksaan, tetapi kami melihat kebenaran Islam. Kami tidak dibujuk, seandainya pun ada paksaan, kami akan disiksa, dan akan dibunuh. Tidak hanya itu, ditelanjangi, diseret sepanjang pantai, dimasukkan dalam WC dan sempat ditikam di leher saya, tapi tidak mempan. Saya yakin Tuhan bersama saya. Hari itu, saya melarikan diri ke hutan, lalu saya ke kota untuk minta diislamkan dan dikhitan".

Dari paparan temuan data yang diperoleh di atas, dapat di analisis, bahwa perpindahan agama menggambarkan proses kreatif, yaitu (1) krisis ekstensial, saat seseorang meraba-raba pertanyaan dasar seperti apa arti hidup, (2) penyerahan diri, mencoba dan gagal menjawab pertanyaan dengan menggunakan sudut pandang kehidupan masa kini, (3) pandangan baru, pertanyaan dapat dijawab dengan menggunakan sudut pandang kepercayaan baru, (4) hidup baru, menghasilkan perubahan perilaku dan cara baru dalam mengatasi masalah kehidupan.

\section{Proses Konversi yang dilakukan}

Proses konversi dapat dibagi menjadi tiga tahapan, sebagai berikut: pertama, dilakukan secara personal. Pada dasarnya, peralihan keyakinan yang dilakukan oleh komunitas mu'allaf ini bersifat personal. Kondisi tersebut dilakukan karena keadaan waktu itu yang menyebabkan mereka tidak mungkin melakukannya secara kolektif dan kolegial. Hampir seluruh tokoh agama dan masyarakat di daerah tersebut beragama Kristen
Protestan. Keberadaan mereka, selain secara sosialbudaya tidak diuntungkan, apalagi dengan frontal menyatakan berpindah agama dari agama mayoritas suku dan komunitas mereka. Sejak kasus yang dikhawatirkan oleh aparat dan tokoh-tokoh agama setempat, mensinyalir akan dibangun sebuah masjid di tengah-tengah mereka. Aparat dan tokoh-tokoh agama Kristen waktu itu, sepertinya alergi dengan masjid sebagai simbol dari eksistensinya kaum muslim. Maka, dalam kondisi seperti itu, Amos dkk melakukan konversi dengan cara berpindah ke Kab. Sorong. Menurut mereka, tidak mungkin akan dapat pindah agama, kalau masih berdomisili di Tambrauw ini. Akhirnya, secara bergantian Amos dkk. menempuhnya. Pada mulanya, langkah ini dilakukan oleh lima orang, yakni, Amos, Yacob, Darwis, Adam, dan ibu Hanifah (Imam, wawancara 14/03/2014).

Walaupun demikian, di dalam perjalanan mereka mendapat siksaan dan ancaman dari sejumlah kalangan Kristen yang mengetahui mereka akan pindah agama. Langkah ini mereka tempuh dengan satu prinsip "Tuhan sudah memberikan hidayah kepada kami untuk memeluk agama Islam". Apa pun yang menimpa, mereka tidak dipedulikan. Keyakinan mereka sudah mantap terhadap agama baru mereka.

Kedua, mengajak keluarga secara diam-diam. Langkah berikutnya yang diambil oleh tokohtokoh kunci tersebut, setelah menyatakan diri resmi beragama Islam, adalah dengan mengajak keluarga mereka pindah dari daerah asal ke Kab. Sorong. Setelah melakukan pengislaman (bahasa mereka dengan istilah sunat) di Kemenag Kab. Sorong, mereka secara berangsur-angsur mengajak istri dan anak-anak mereka untuk memeluk Islam. Kepindahan yang mereka lakukan adalah simbol, bahwa mereka memeluk agama baru secara resmi, tanpa paksaan dari mana dan siapa pun juga. Berpindahnya keluaga dan anak istri mereka dari daerah asal, setelah kondisi relatif stabil, apabila dibandingkan dengan beberapa bulan sebelumnya. Mereka simpatik kepada agama Islam. Langkah ini dilakukan oleh tokoh-tokoh kunci tersebut, untuk menghindari bencana yang akan dilakukan oleh aparat pemerintah ketika itu. Dalam proses konversi ini, kondisi mereka berjalan sebagaimana harapan. Menurut wawancara dengan informan, langkah ini murni dilakukan untuk menghindari ancaman, bahkan pembunuhan massal yang akan dilakukan oleh aparat dan tokoh-tokoh agama Kristen Protesten setempat. Dalam pemahaman 
komunitas mu'allaf, langkah ini memang berat, tetapi harus diambil langkah-langkh praktis untuk menyelamatkan diri dari ancaman yang akan dan telah dilakukan oleh tokoh dan aparat setempat (Amos, wawancara 13/03/2014). Dengan sarana transportasi seadanya ketika itu, dapat dibayangkan betapa berat perjuangan dan pengorbanan mereka, hanya untuk mencari identitas religius mereka.

Ketiga, menyembunyikan identitas selama beberapa tahun. Banyak cara yang ditempuh untuk mencapai tujuan. Dari hasil wawancara penulis mengungkapkan, perjalanan dan pengalaman pindah agama dari komunitas mu'allaf cukup bervariatif. Menurut Adam dkk. secara diam simpati kepada Islam. Namun rasa simpati tersebut tidak dapat diungkapkan secara langsung karena kondisi keluarga dan lingkungan yang tidak memungkinkan. Rasa simpati itu, ditinjaklanjuti dengan penghayatan subyek tergerak untuk bertanya kepada salah satu guru imigran yang beragama Islam di daerah tersebut mengenai ajaran agama Islam sesungguhnya. Ketertarikan tersebut membuat sejumlah komunitas bertanya kepada guru yang berasal dari agama Islam tersebut. Melalui guru inilah, pengetahuan Adam dkk. mengenai ajaran agama Islam didapatkan.

Fenomena pindah agama sebagai suatu perubahan dramatis, tentunya tidak sekadar berimplikasi terhadap diskontinuitas identitas religius di masa lalu. Pindah agama merupakan sebuah perubahan signifikan; sebuah proses yang memungkinkan seseorang untuk melakukan evaluasi terhadap dirinya dan komunitasnya, sehingga perubahan identitas religi diharapkan membawa penghayatan yang lebih mantap akan hakikat kebenaran beragama. Maka dalam konteks ini, proses konversi pindah agama menjadi hal yang menarik untuk diungkap lebih dalam. Pencarian makna dan tujuan hidup, kiranya mengiringi setiap perjalanan manusia. Perjalanan spiritualitas komunitas mu'allaf yang terjadi pada suku Abun mempunyai proses yang sangat panjang dan berliku. Untuk itu, mengetahui bagaimana proses konversi pindah agama yang mencakup perubahan kognitif, afektif, dan perilaku penting diungkapkan.

\section{Dampak Psikologi}

Dalam perjalanan konversi pindah agama seringkali menyangkut peristiwa emosional yang mengguncangkan batin para pencari Tuhan (Hanna, 2005: 34). Dalam keadaan tersebut, komunitas mu'allaf suku Abun secara aktif berusaha mencari pemenuhan diri guna mengatasi krisis yang dialami. Masa pencarian ini secara emosional mempengaruhi pilihan religiusnya. Hambatan dari aspek sosial budaya berpotensi mengurungkan niat untuk melanjutkan pencarian jati diri dalam beragama.

Dalam melakukan sesuatu yang tidak cocok dengan sikap komunitas dan suku-suku lain, menyebabkan komunitas mu'allaf ini mengubah sikapnya sendiri. Penelitian ini dapat dicontohkan dengan peristiwa munculnya dampak negatif dan upaya untuk mengimbangi agar komunitas tetap pada pilihan untuk berpindah. Untuk mengurangi ketidakcocokan, komunitas mu'allaf melakukan perilaku-perilaku untuk meyakinkan dirinya mereka sendiri. Mencari informasi untuk menguatkan perilakunya dan mencontoh seseorang yang sukses dengan perilaku tersebut.

Tekanan batin yang selama itu menimpa mu'allaf dari suku Abun adalah sebagai berikut (H.Lukman Yenjau, wawancara 7/10/2013): 1) Suku-suku lain yang beragama Kristen di daerah tersebut menjadi daya kritis tersendiri. Percekcokan, kesepian batin, tidak mendapat tempat dalam hati kerabat, juga menjadi masalah serius di dalam batin mu'allaf. 2) Keadaan lingkungan yang menekan dan menimbulkan problem pribadi, adanya rasa terlempar dari kehidupan kelompoknya, lantas hidup dengan cara yang tidak biasa. 3) Kemiskinan, walaupun sifatnya tidak mutlak, tetapi menjadi problem serius pada batin para pencari Tuhan ini.

Dari sini dapat dikatakan, bahwa konversi agama merupakan proses yang jauh dari sederhana. Proses ini dipengaruhi oleh faktor-faktor kontekstual yang membentuk ruang lingkup komunikasi, memberi gambaran pilihan religius yang tersedia, serta mobilitas, fleksibilitas, sumber-sumber, dan kesempatan bagi komunitas mu'allaf yang pindah agama.

Perkembangan keagamaan komunitas dapat tercapai pada tingkat kematangan beragama dibutuhkan suatu proses panjang. Proses tersebut, boleh jadi karena melalui proses konversi agama pada diri, atau karena bersamaan dengan kematangan kepribadinya. Pada tahap kedewasaan awal, telihat krisis psikologis yang dialami oleh komunitas mu'allaf ini karena adanya pertentangan antara kecenderungan untuk mengeratkan hubungan. Ungkapan kematangan mental yang telah terbentuk sejah 20 tahun yang lalu, sekarang terbukti ketika kaum Muslimin yang datang ke daerah tempat mereka tinggal, selalu terdengar 
sambutan hangat yang diiringi dengan ungkapan salam. Penulis, ketika pertama kali memasuki komunitas mu'allaf tersebut merasa terkejut dengan ungkapan salam yang diberikan oleh sejumlah komunitas mu'allaf tersebut. Sikap dan perlakukan mereka yang sederhana dan santun mengasumsikan telah terjadi kematangan mental dan spiritual dalam beragama. Tampaknya, tauhid mereka sudah berurat dan berakar dalam sendi-sendi kehidupan mereka. Kematengan tauhid secara tidak langsung berpengaruh kepada sikap (afeksi) komunitas mu’allaf ini (Ali, 1995:44). Oleh karena itu, manusia bisa beriman dengan ciptaan ini, karena berfikir (Sulaiman Yenjau, wawancara 18/08/2013).

\section{KESIMPULAN}

Pindah beragama (Religious conversion) dapat dimaknai sebagai sebuah proses berpindahnya kepercayaan, keyakinan, dan praktik dari suatu rangkaian ajaran tertentu (nilai spiritual), kepada seperangkat kepercayaan, keyakinan, dan praktik ajaran lain. Tetapi, proses konversi tidaklah semudah yang dibayangkan masyarakat. Dampak dan pengaruhnya, demikian terasa dalam kehidupan. Maka, ketika berbicara mengenai hakikat agama (Religious matters), yakni apa yang individu yakini tentang Tuhan, spiritualitas, dan justifikasi tentang Tuhan; spektrum emosional suka-tidak suka; dan domain perilaku, yakni apa yang dilakukan dan bagaimana sebuah tindakan dilakukan.

Konversi agama yang dilakukan suku Abun di Kabupaten Sorong ini, agama lebih dimaknai sebagai fungsional praksis dalam kehidupan mereka. Dari hasil penelitian yang telah dilakukan terhadap proses konversi agama ini dapat disimpulkan dengan beberapa poin penting sebagai berikut: faktor utama yang menyebabkan mereka berpindah agama dari Kristen Protestan ke dalam Islam antara lain: faktor sosial, budaya, tokoh spiritual yang misterius, serta hidayah langsung dari Allah yang menggerakkan hati mereka. Mereka percaya bahwa Allah telah membukakan hati dan pikiran mereka untuk melihat kebenaran Islam. Rintangan yang mereka hadapi seolah tidak diperhatikan karena faktor-faktor tersebut telah merasuk ke dalam hati nurani.

Sedangkan kronologi pindah agama yang mereka lakukan meliputi tiga tahapan utama, yakni, secara person (sendiri-sendiri), mengajak keluarga setelah pindah dari Kabupaten Sorong, serta pindah agama yang dilakukan dengan menyembunyikan identitas mereka, selama beberapa tahun kemudian menyatakannya secara terus terang bahwa mereka telah masuk Islam. Tahapan terakhir ini dilakukan karena krisis sosial ketika mereka di kampung asal.

Dampak psikologis yang dialami komunitas mu'allaf tersebut bukanlah beban ringan. Banyak kendala dan rintangan yang mereka hadapi. Kendala utama yang dihadapi oleh para pencari Tuhan ini adalah ketegangan dan kritis batin yang cukup berkepanjangan. Demikian pula kekerasan fisik yang mereka terima dari oknum aparat, serta pengeroyokan oleh sejumlah masyarakat dari suku Biak tidak dapat diindahkan. Hinaan dan caci maki bagi pencari Tuhan ini, menjadi hal yang biasa mereka terima dari lingkungan sosialnya. Di samping, itu dampak positif yang mereka rasakan setelah berhasil keluar dari kampung halaman adalah perubahan sikap dan mental. Mereka sudah merasa tenang dan tenteram dalam kebenaran Islam. Hidup yang mereka jalani terasa tanpa beban, walaupun mereka secara ekonomi sangat memperihatinkan.

\section{UCAPAN TERIMA KASIH}

Terima kasih penulis ucapkan kepada masyarakat Suku Abun pada umumnya yang telah memberikan pengalaman dan informasi terkait penelitian yang dilakukan. Terkhusus kepada Kepala Suku Abun Bapak H. Lukman Yenjau, Ibu Hamidah Yenjau, Bapak H. Tejo, Bapak Sulaiman Yenjau, dan seluruh informan peneliti yang tidak dapat penulis sebutkan satu per satu.

\section{DAFTAR PUSTAKA}

A.M. Hardjana. A.M. 1992. Penghayatan Agama: Yang Otentik don Tidak Otentik. Yogyakarta: Kanisius.

Abidin, Z. 2002. Analisis Eksistensial Untuk Psikologi dan Psikiatri. Bandung: PT Refika Aditama.

Abidin, Z. 2002. Analisis Eksistensial Untuk Psikologi dan Psikiatri. Bandung: PT Refika Aditama.

Ali, H.M. Mukti. 1995. Alam Pemikiran Islam Modern di Timur Tengah. Jakarta: Djmbatan.

Bagus, L. 2000. Kamus Filsafat. Jakarta: PT Gramedia Pustaka Utama.

Bustanuddin, Agus. 2005. Agama dalam Kehidupan Manusia. Jakarta: Rajawali Press.

Crapps, R.W. 1994. Perkembangan Kepribadian dan Keagamaan. Yogyakarta: Kanisius.

Djumhana Bastaman, Hanna. 2005. Integrasi Psikologi dengan Islam; Menuju Psikologi Islami. Yogyakarta: Pustaka Pelajar.

Fisher, Aubray Fisher. 1989. Teori-Teori Komunikasi. 
Bandung: Remaja Karya.

Moleong, Lexy J. Moleong. 2004. Metodologi Penelitian Kualitatif. Bandung: Remaja Rosdakarya.

Mulyana, Deddy. 2001. Metodologi Penelitian Kualitatif: Paradigma Baru Ilmu Komunikasi dan Ilmu Sosial Lainnya. Bandung: Rosdakarya.

Munawar-Rachman, Budhy. 1995. Agama Masa Depan; Perspektif Filsafat Perennial. Jakarta: Paramadina.
Norma Permana, Ahmad. (ed.). 2000. Metodologi Studi Agama. Yogyakarta: Pustaka Pelajar.

Pargament, K.I. 2000. The Psychology of Religion and Coping. New York: The Guilford Press.

Qatloly, Aholiab. 2013. Sosio-Epistimologi, Membangung Pengetahuan Berwatak Sosial. Yogyakarta: Kansius.

Rakhmat, Jalaluddin. 2000. Psikologi Agama. Jakarta: PT Raja Grafindo Persada.

UUD '45 dan Amandemennya. 2002. Surakarta: Penerbit Pustaka Mandiri. 